\title{
Retroactive Subjectivity in Documentary Film
}

This article endeavours to contribute to the growth of psychoanalytic documentary film theory by exploring the figurability of subjectivity in compilation film. It does this by intersecting psychoanalysis with compilation film through the notion of non-linear temporality. It takes the Lapalnchian notion of aprés coup as a central concept to interrogate the multiple synchronous time lines found in compilation film, as well as the multiplicity of temporal inscriptions of memory found in the unconscious. While both domains have radically different ends, the process of retroactive inscription of subjectivity can be seen to function in both fields. This theoretical understanding is applied to Jonas Mekas' Outtakes of a Life of a Happy Man (2012). In this analysis the article suggests that Mekas' subjectivity is represented by the use of a particular temporal gaze that enables the archive and memory to remain perpetually open to resignification.

Keywords: après coup; retroactive subjectivity; compilation documentary film; psychoanalytic documentary film theory; Jonas Mekas 


\section{Introduction}

This article explores the figurability of the unconscious in compilation film. In considering how film may document the inner world, a central paradox emerges — that of looking from the outside while seeing on the inside. Interestingly, this contradictory simultaneity of interior and exterior perspectives is evident in the coterminous inception of psychoanalysis, film and the X-Ray that took place in quick succession in 1895. These fin de siècle discoveries share the same period of origin and appear, as Lippit has observed, 'to be inextricably fused to one another, appropriating each other's features, functions, and rhetorical modes' $(1996,76)$.

The correspondence of film to Sigmund Freud's meta-psychological model of the mind, has lead theorists, such as Laura Mulvey, to call it the 'philosophical toy' or an 'allegory' of human consciousness' (2003, xvi). This interrelatedness between psychoanalysis and, almost exclusively, narrative film has also generated a rich intellectual domain. Influenced by Jacques Lacan's return to Freud, the work of JeanLouis Baudry (1974), Roland Barthes (1980) and Christian Metz (1982) in France, and Mulvey (1975) and Colin MacCabe (1985) in the United Kingdom, laid the foundations for the development of psychoanalytic film theory. This not only included the interpretation of the filmic text but also the analysis of the cinematic system, comprised of the film apparatus and the screen, on the one hand, and their relationship to the spectator on the other. Psychoanalytic film theory has also been characterised by the original work of feminist film scholars such as Mulvey $(1975,1989)$, Mary Ann Doane (1987) and Vicky Lebeau (2001), who have explored sexuality, gender stereotypes, fetishism and the masculine gaze engendered by the Hollywood film. In this context, psychoanalysis was employed, as Michael Renov (2014) suggests, as a means of trying to comprehend and account for the seductiveness of the filmic text, to get beneath and decode its symbols, images and sounds. 
In sharp contrast to this rich and sustained intellectual history, the psychoanalytic enquiry into the representation of real people, places and events central to the documentary film project — has only recently begun. Bill Nichols' muchmaligned description of documentary film as the 'discourse of sobriety' $(1999,3)$ situated it as incompatible with psychoanalysis. Documentary film's early alignment with rationalism precluded a deeper investigation into its more hidden dimensions, latent meaning and unconscious dynamics. Notable exceptions to this include the writings of Renov (1993, 2004, 2014), working primarily at the site of the audience, who notes that the documentary gaze is constituted by a 'charged vision' (2004); one filled with both conscious motives as well as unconscious desires. Similarly, Elisabeth Cowie $(1999,2011)$, also working at the site of the audience, has explored the epistephilic gaze. She extends understanding to include the identification of the documentary film viewer as the subject of knowledge, driven by the often-hidden pleasure of knowing-through-looking (1999). For Cowie, documentary film is a twofold process that involves recording reality, desiring the real. In this light, documentary film, Cowie suggests, is the discourse of desire (1999) and the discourse of the university (2011). Agnieszka Piotrowska (2013) has moved the discussion away from the site of the audience to the site of production by focusing on transferential dynamics between the documentary filmmaker and the documentary subject. By placing this relationship as central to the documentary film project, she argues that it may be better understood as the discourse of the analyst or the hysteric.

This paper endeavours to contribute to this growth of psychoanalytic documentary film theory. It does this by intersecting psychoanalysis with compilation film through their respective relationships to temporality. As Mulvey (2007) has noted, the relationship between the filmic past and present is not as complex as the emergence 
of unconscious material and its subsequent interpretations in clinical psychoanalysis. However, as Mulvey thoughtfully goes on to argue, 'an enquiry into one structure enables the enquiry into the other' (Ibid., 110). The multiple synchronous time lines found in both psychoanalysis and compilation film provide such a point of enquiry into both domains.

As such, this paper draws on the notion of après coup or afterwardsness, to explore the representation of subjectivity in documentary film, where the visual archive and its association with memory, may remain open to retroactive resignification. ${ }^{1}$ This investigation is done through a two-fold process. The first involves a theoretical exploration of the etymology of the term après coup, along with its relationship to compilation film. Secondly, it employs this understanding to explore compilation filmmaking, exemplified by Jonas Mekas' Outtakes of the Life of a Happy Man, that premiered at the Serpentine Gallery London in 2012. In doing so, this paper aims to inform the practice-based and theoretical understanding of the figuration of interiority in documentary film. Mekas' film is a useful text for a psychoanalytic investigation as it uses and repeats time in ways that can be considered similar to psychoanalytic notions of temporality found in the unconscious. As this use of time is characteristic of his work, it makes his oeuvre highly appropriate for discussion. However, prior to analysing his film, this paper first examines the concept of après coup, while

${ }^{1}$ The Oxford English Dictionary defines the archive as 'a collection of historical documents or records providing information about a place, institution, or group of people'. The analogous relationship between the collection of historical documents or records stored in the 'archive' of the unconscious, to that of the film archive, drawn from in the construction of the compilation film, is explored in the remainder of this article. 
simultaneously acknowledging that an extensive tracing of this notion is also beyond its scope.

\section{Intersecting Après Coup and Compilation Film}

\section{Après Coup}

The term 'après coup' marks a particularly French rereading of Freud's concept of Nachträglichkeit, or afterwardsness (après coup). The technical use of the term nachträglichkeit was first used in Freud's case history of the 'Wolf Man' (From the History of an Infantile Neurosis, 1918). Freud notes that 'the period of time during which the effects were deferred is very greatly diminished' (58). This illuminates the period and distance between the Wolf Man's witnessing of the primal scene and his anxiety dream, which formed the basis of Freud's analysis. Rosine Perelberg (2008). situates après coup as a central idea in Freud's work. It is conceived as principal in the formation of psychical life and subjectivity, where the traumatic effects are understood as the reverberation or 'structural dialectic' (Doane 2002, 36) between two events separated across time. ${ }^{2}$

The etymology of après coup is complex and contested, straddling different interpretations and cultural traditions. Dana Birksted-Breen (2003) has noted that Lacan was pivotal in revitalising Freud's concept of Nachträglichkeit, which had been overlooked, possibly — as Jean Laplanche and Jean-Bertrand Pontalis (1985) suggest

— because James Strachey did not always translate the same word. The terms

\footnotetext{
${ }^{2}$ This understanding of dialectics, used here, draws on the Hegelian use of the term as 'the process of thought by which apparent contradictions (which he termed thesis and antithesis) are seen to be part of a higher truth (synthesis)' (Oxford English Dictionary).
} 
'nachträglich' (adjective) and 'Nachträglichkeit' (noun) carry different meanings and this seems to be due to the varying uses of the term by Freud. John Fletcher in a footnote in his book Freud and the Scene of Trauma (2013), has observed that Freud took an ordinary German word nachträglich (later, afterwards, subsequently) and turned it into an abstract noun nachträglichkeit, which broken into its components reads as nach/after, tragen/to bear or carry, suggesting that its literal translation is to 'carryingafter-ness' (61). Despite Lacan's revival of the term, it was Laplanche's long-standing work on the concept that provides a more recent translation of the term 'afterwardsness' or après coup in French (1999).

The term après coup is associated with trauma, which is a central component in the understanding of this phenomenon. Trauma, for Freud, as Fletcher (2013) articulates, may be regarded as when 'an excessively intense and incompatible idea confronts and threatens to overwhelm the ego, leading to its exclusion or repression from consciousness' (61). Fletcher goes on to explain that 'this moment of trauma, is then followed by an auxiliary moment or moments where the split-off group of representations temporarily returns to or converges with consciousness' $(2013,60-61)$. This corresponding set of terms 'traumatic' and 'auxiliary' evokes a system of 'scenes', a psychical scenography, governed by a distinctive temporal logic.

This distinctive temporal logic is evident in Freud's understanding of the biphasic nature of childhood sexuality and its connection with the notion of après coup is readily observable in his case study of Emma. In the 'Project for a scientific psychology', Freud (1895) relays the narrative of Emma whose recent symptoms included the inability to enter a shop unaccompanied. Early in her analysis, she recalls an incident at the age of twelve when, upon entering a shop and seeing two shop assistants laughing, she took fright and ran away. Later in her analysis a second earlier 
memory emerged when, at the age of eight, she entered a sweet shop and the shopkeeper touched her genitals whilst smiling at her. The psychoanalyst, Megan Virtue, in an unpublished conference paper (2013), suggests that...

since by the age of twelve she had reached puberty, the memory of the first experience at eight then became active in arousing a sexual release, which was transformed into anxiety.

In this way, the meaning of the laughing assistants could be understood in light of the second memory, which had occurred earlier chronologically. Virtue argues that the sexual maturation is the pivotal element, which enables resignification of the first element that then became traumatic après-coup. It is the developmental experience of puberty that produces a different psychical understanding of what had gone before, which is now experienced as traumatic. In this light, Freud's conceptualisation of trauma and temporality are intricately bound, where memory is inscribed across multiple temporalities.

Exploring the varied meanings and their relationship to temporality further, Birksted-Breen (2003) suggests three different uses of the term après-coup. The first use simply means 'later'. The second term suggests a movement from past to future. It is as if 'something is deposited early on in the psyche of the individual' (1501), which is only later activated. This is connected to the seduction theory where the trauma is constituted in two stages. According to Laplanche and Pontalis (1973), this describes something of a delayed action bomb and approximates to Strachey's translation of Nachträglichkeit as deferred action. The third use, and the one least found in Freud but developed initially by Lacan and then further by French psychoanalysts, particularly Pontalis, implies that something is perceived but it only takes on meaning retrospectively, from the position of the present. It is this third use of après coup that 
refers to the retrospective attribution of meaning — a retroactive resignification that occurs après coup (afterwardsness) — that will be used as the preferred term in this paper. Further, while the concept is rooted in trauma, it is used more broadly in this paper, and with greater elasticity, to refer to the production of a different psychical understanding in relation to the reverberation of a 'system of scenes', across a multiplicity of temporalities.

Freud's discovery of the atemporality of the unconscious opens up and enables the reworking of meaning and memory après coup. It moves away from the representation of a linear succession of moments — past, present, future — and relates to the notions of individual history and rememoration. The concept après coup further challenges linear notions of temporality by arguing that what comes afterwards may give meaning to what has come before. This suggests that the distinct and particular meaning of an event or phenomenon can never be fully known in the here-and-now. Although it can be informative, the meaning of the 'now' moment retains an unknowable element that may gain signification, not from the past but from a future event.

Interestingly, Perleberg identifies several temporalities in Freudian metapsychology that are helpful to consider in relation to documentary film. These temporalities characterise a model of mind with après coup forming the central axis of understanding. This includes: development, regression, fixation, repetition compulsion, the return of the repressed, the timelessness of the unconscious and après coup. Perelberg conceptualises these temporalities within a model of the mind like a heptagon in motion where après coup 'illuminates everything else' $(2008,32)$. It is useful to note that this conceptualisation of temporality may be regarded as idiosyncratically psychoanalytic and useful to consider in relation to the development of psychoanalytic 
documentary film theory. It is this multiplicity of time and retroactive resignification of a psychical scenography, which forms a bridge to compilation film, discussed below.

\section{Afterwardsness and Compilation Film}

Prior to linking the notion of après coup with compilation film, it is useful to first unpack this documentary film form. Compilation film is an often-neglected early method of visual knowledge production, attributed to the pioneering work of Esfir Shub and her film The Fall of the Romanov Dynasty (1927). Drawing on footage of the Romanov family that she discovered in rusting cans stored in Leningrad cellars, she was able to weave 'a sustained tapestry from the fragmented snippets by treating them as historical data' (Chanan 2007, 260). This constructivist method of producing knowledge has gathered support and can now be seen as a staple of contemporary documentary filmmaking practice. Of importance for the development of a psychoanalytic understanding of its production is that it constructs meaning retrospectively based on the understanding and reworking of existing historical footage and archive material.

In attempting to define the compilation film, Sjöberg (2001) suggests that there is no clear vocabulary to describe it, possibly due to the fact that it has been undertheorised. However, Sjöberg (2001) draws on two seminal texts to inform his understanding of compilation film, namely the works of Jay Leyda's Films Beget Films (1963) and W.C Wees' Recycled Images (1993). Sjöberg (2001) suggests that compilation film needs to be contextually considered when used as 'a strategy for making film using other people's material' (Ibid., 23; emphasis in original). One of the defining characteristics of compilation film is its 'inherently self reflexive potential' (Ibid., 18), which actively reveals and is conscious of its constructed form. The multiple strategies of compilation film include, according to Sjöberg (2001, 23), the found object 
(in the tradition of Duchamp), montage, bricolage, superimposition, using footage from singular or multiple films. ${ }^{3}$

In a short section of his book, Sjöberg makes tentative links between the form of the compilation film and the unconscious through exploring the compilation film of the surrealists. Linking the dream image with surrealist compilation film, he asks if the surrealist compilation films can 'perform, or participate, in an alternative system of communication that draws on an implied logic of the unconscious found in our understanding of the dream' $(2001,232)$. However, his exploration in relation to compilation film and psychoanalysis is limited, and avoids any further exploration of working with what he considers to be, 'the heavy and often cumbersome baggage of psychoanalytic theory' (Ibid., 232). He does make an interesting point, though, when he suggests the use of compilation film as a means of analysing the dream. He draws the analogy between the archive and the archive of images of the unconscious, saying 'we understand dreams as fragments from our experiential archive that resurface in new configurations and surroundings - figurative, yes but not quite real' (Ibid., 232). In this light, it is possible to consider how compilation film may illuminate and draw greater attention to the 'editing' process implicit in the reconfiguration and secondary revision in the dream work, which draws on the mind's internal visual storehouse of images. ${ }^{4}$

${ }^{3}$ For scholars, such as Russell (2017), the compilation film may also be regarded as an essay film. She develops the notion of 'archiveology', which she suggests bridges experimental film and documentary practice, usually through the essay film.

${ }^{4}$ This analogy between the archive and the archive of the unconscious similarly resonates with Derrida's seminal work Archive Fever (1996), where the structure of the archive comes close to the structure of memory and the unconscious itself. 


\section{Enfolding Compilation film with après coup}

The exploration of the relationship between the psychoanalytic concept après coup and film studies has been significantly underdeveloped. Exceptions to this include the work of Paul Sutton (2004) who has, in complex ways, established links between film spectatorship and après coup. Sutton suggests a spectral paradigm in which the viewer remakes films 'as part of the very process of spectatorship and that beyond the actual cinematic experience, they carry a remade and remembered "film" with them.' (Sutton 2004, 385). The film may be remade in viewers' minds, après coup, through their transferential relationship to the filmic experience. Piotrowska (2014) has explored the notion of après coup in documentary film, locating it within the potentially transformative transferential relationship between documentary subject and filmmaker. While Richard Rushton (2004) has explored the notion in relation to the structure of trauma in narrative film, it is Mulvey's (2007) exploration of the relationship between the narrative structure in compilation film and après coup that has the most significance for the folding-in of psychoanalysis with compilation film.

Mulvey (2007) observes the double time structure inherent in compilation film, following the process in which old film material is reassembled into new. She notes that it is this double temporal structure that, through analogy, links to psychoanalytic theory, where the trace of trauma in archive film may be resignified après coup, in compilation film. As compilation films are made from pre-existing footage, as Mulvey notes, a new narrative and consciousness may emerge out of old footage. She writes: 'As a result from the process of reassembling, the old into the new, all compilation films have a double time structure, all consist of pre-existing material, which is then reassembled into a new film' $(2007,109)$. She identifies this double time structure as opening up 
compilation film to psychoanalytic theory, while at the same time, she is careful not to reduce one to the other.

The relationship between compilation film and après coup can be further understood where historical footage is reorganised or resignified in a new light in relation to what has come after. In psychoanalytic treatment, this can be understood as a particular kind of insight that produces a substantial structural change to subjectivity. It is marked by certain moments in an analysis where, as the psychoanalyst Sodre suggests, 'something may be understood that suddenly reorganises the patient's way of thinking about a past event or particular object relationship' $(1999,214)$. She provides an illuminating image of the kaleidoscope for this reorganisation, suggesting that this change in viewpoint makes a new image appear; 'the elements stay the same, but the resulting figure is nonetheless quite different' (Ibid., 214). Although Sodre is writing of a metaphoric image, it is useful to consider it in relation to documentary film too. Compilation film can also be regarded as having an analogous relationship, where the meaning of footage is reorganised in relation to other images - similar to a turn of the kaleidoscope that reorganises meaning après coup. This retroactive resignification or insight is not (necessarily) dependent on new information but on a way a past event is (re)interpreted from a future or new position.

This conceptualisation of how images may be resignified brings to mind the work of Walter Benjamin's Arcades Project (1999), in which he provides an enigmatic and elliptical account of time in relation to the dialectics of the image. His description is evocative of the notion of après coup and begins to approximate the relationship between time and the image explored above. Benjamin writes: 
It's not that what is past casts its light on what is present, or what is present its light on the past; rather, image is that wherein what has been comes together in a flash with the now to form a constellation. In other words, image is dialectics at a standstill. For while the relation of the present to the past is a purely temporal, continuous one, the relation of what-has-been to the now is dialectical: is not progression but image, suddenly emergent. $(1999,462)$

This temporal constellation of the dialectics of the image, where images may reverberate with each other across points in time, results in a new image emergent through the paradox of 'dialectics at a standstill'. One characteristic of this process in compilation film is that the indexical or trace image, inherent in existing film, is resignified resulting in a re-making of new meaning, and in turn, a new personal history. This process involves the semiotics of memory, loss, absence and trace, which forms the focus of the next section.

\section{History and Memory Post Factum}

Implicit in the resignification of historical or archive footage within compilation film is its close affinity to memory. Archive film suggests an uncanny resemblance to recollection where the once profilmic events, now forever beyond reach, leave their photochemical trace on film with mechanical verisimilitude. Film's capacity for indexical inscription links film — located in the present — with people, places and events of the past. Further, over and above its indexicality, it is the iconic nature of archive footage that enables it to be closely aligned to memory itself. Hall suggests that visual signs may be regarded as iconic when 'they bear, in their form, a certain resemblance to the object, person or event to which they refer' $(1997,20)$. He goes on to note that the iconic image reproduces a similarity of actual conditions of perception within the visual sign. Clearly all film has the potential to generate iconic imagery, however, as documentary film records real people, places and events, the iconicity of 
documentary film takes on an additional dimension as it is predicated on the historical past. The seeming accuracy of the archive footage to recall history suggests a mechanical perfection of memory beyond the fallibility of the human mind. This makes it an attractive medium for the reworking of memory as well as the past.

Archival footage is also produced in particular historical and social contexts. The film scholar Belinda Smaill notes that there is a need to 'grasp the particularity of historical contextualisation' $(2010,8)$ which inevitably impacts on its textual production. Similarly, Chanan notes — in relation to what Kracauer called 'the seizure of reality' $(2007,14)$ which informs the documentary film project — that the image is always coded through the double function of index and icon.

However, as Nichols has observed, the iconicity of the archival footage also presents an epistemological problem. There is a tendency, Nichols suggests, that we assume historical images to be authentic and that 'we know the past by (re-)seeing it' (1993, 177-178). The archive footage along with the iconic nature of its images bears an uncanny relationship to memory. In sharp contrast to the mimetic relationship between images and memory, Janet Walker's monograph, Trauma Cinema:

Documenting Incest and the Holocaust (2005), speaks directly to the representation of absence and the disruption of memory through trauma. She thoughtfully coins the term 'traumatic paradox' (4) to refer to the way that traumatic events produce gaps and mistakes in memory, which in turn undermine the legitimacy of the very incident that they try to recall and represent. As such, archival footage is often — and at times problematically — treated as 'if they are memory itself' (MacDougall 1998, 232), rather than a referent of memory. This also presents a challenge, as MacDougall has observed, that 'memory offers film its ultimate problem: how to represent the mind's landscape, whose images and sequential logic are always hidden from view' (1998, 231). Although 
it is never possible to 'see' this mental inscape, these archival images may be employed in the service of interior observation through the compilation film. Through a mimetic correspondence, this relationship raises the potential for the figurability of the unconscious in documentary film, despite Freud arguing against the possibility of its visual representation. In Civilization and its Discontents he writes:

\footnotetext{
The fact remains that only in the mind is such a preservation of all the earlier stages alongside the final form possible, and that we are not in a position to represent this phenomenon in pictorial forms. $(1930,71)$
}

It is interesting to note that Freud does make one possible exception to the representation of the psyche in his exploration of the Mystic Writing-Pad (1925). In this paper Freud places an object in analogous relationship to his topographical model of the mind. The Mystic Writing-Pad usually takes the form of a child's toy. It is a wax tablet covered by a clear membrane so that graphic marks made on the surface with a stylus, can be simply removed by lifting the membrane. However, the wax slab beneath retains the impression of all that was inscribed on its surface.

Although Freud in his articulation of the object describes a literary process of trace, it is interesting to note how this description begins to come close to the Piercian notion of index, and the on-going links to the indexical image in documentary film. This palimpsest quality of the Mystic Writing-Pad was not extended to the graphic potential of film. However, it may find its visual equivalent in the compilation film which makes use of superimposition, jump-cuts, cross fades and other visual transitions characteristic of non-linear editing. Doane notes that Freud, particularly in his early works, was 'obsessed with the issues of traces and recordings, of a space of psychical representation and the problem of its limits' $(2002,34)$. However, documentary compilation film may lay down signifiers of memory as permanent trace — and make room for further 
recordings. The potentially limitless storage capacity of digital technology used in film, also points to the limitless quality of the Mystic Writing-Pad to absorb representations and begin anew. As such, through the increased accumulation of public and domestic film archives, documentary film begins to tantalisingly suggest an alternate psychoanalytic model of the mind and its processes of memory. At the moment that Freud chose the Mystic Writing-Pad as his paradigm to describe representations of memory in the mind, film was still in its infancy. Now with the proliferation of the archive, it is possible to speculate if a closer model might be more akin to the documentary compilation film. As noted by Doane (2002), Freud does not select cinema, photograph or phonography as an analogous model of the mind but rather the comparatively old-fashioned Mystic Writing-Pad.

\section{Narrative and historical truth}

In considering the truth claims involved in the reconstruction of memory from the archive, après coup, it is important to note, what the psychoanalyst Spence $(1982,177)$ calls the difference between historical and narrative truth. The hermeneutic approach of documentary compilation film, which draws on the archive in the construction of memory, should be cautious in its claims to reconstruct the 'real' historical past. Informed by the work of Spence (1982), the psychoanalytically understood compilation should establish internal narrative cohesion as a criterion for its truth claims. Spence writes about this in relation to psychoanalytic treatment, which has equal relevance for the use of compilation film explored here. While reconstructions within psychoanalysis can generate meaningful hypotheses, they cannot insist on any direct claims to knowing the past. Spence argues that the construction of the past is a creative process of a 'plausible coherent narrative of our patient's life' $(1982,177)$ and warns of the dangerous slippage of narrative truth becoming accepted as historical truth. A similar 
debate can be found concerning reconstructions and 'false memory syndrome' in psychoanalysis. Fonagy and Target note that the growth in 'false memory syndrome' $(2003,22)$ may be due to the too ready inference by an overzealous therapist that their patient was seduced in childhood. This has led to a possible 'narrative truth' being taken firmly as 'historical truth', which may then lead to embattled legal processes. This is not in any way to turn a blind eye to the real possibility of childhood abuse and its prevalence; rather, the move from narrative truth to historical truth needs careful consideration in both clinical practice and in compilation film. ${ }^{5}$ Further, the aim is not to resolve this debate but to explore how compilation film may productively blur the distinctions between, and open up discussion around, internal and external factors in the formation of memory and its resignification après coup.

Following this theoretical investigation, it is now possible to explore the idea of après coup through Jonas Mekas' compilation film Outtakes of a Life of a Happy Man (2012)

\section{Jonas Mekas' Outtakes of a Life of a Happy Man}

Jonas Mekas' film, Outtakes of a Life of a Happy Man (2012) provides an opportunity to explore his compilation film and how it might inform the notion of a visual retroactive resignification of meaning and memory in relation to the archive. While it may be considered an exemplar of a visual après coup, it should be noted that it is also an exception as Mekas draws on his own personal archive in the making of Outtakes

\footnotetext{
${ }^{5}$ This prevalence of real rather than imaged sexual abuse, Masson argues, is behind all serious neurosis. Masson criticises Freud and psychoanalysis for not accepting this more fully. For a thorough critique of Freud's seduction theory, see Masson's book The Assault on Truth: Freud's Suppression of the Seduction Theory (1984).
} 
(2012). Traditional forms of compilation usually make use of existing and found archives for their remaking into new films.

Mekas is regarded as one of the foremost experimental filmmakers of the twentieth century. It is evident that Mekas has a life-long commitment to making films. As noted by Renov, Mekas exemplifies documentary film's tendencies to 'record, reveal, or preserve' $(2004,74)$. Despite the sense of modesty of his films, they have accrued tremendous significance over time and he has exhibited in all major galleries, festivals and his work is screened globally. It can be understood that for Mekas work and life are intertwined. At the Psychoanalysis and Documentary Film conference at University College London (UCL) in 2013, the film curator, Gareth Evans argued that Mekas demonstrated a particular kind of embodiment as he is constantly accompanied by his camera, which may be regarded as an extension of his own being. Evans points out that it appears for Mekas, the camera and the person are indivisible. Mekas remained extraordinarily productive well into his 90 s and continued to post films on his website. Interestingly, Evans (2013) attributed Mekas' longevity to this embodied relationship and commitment to film and the recording of his life.

\section{Retroactive resignification}

In 2012, for his exhibition at the Serpentine Galley, London, Mekas premiered his film Outtakes of a Life of a Happy Man. The film also was the flagship of a retrospective screening of his works at the British Film Institute (BFI) that coincided with the screening at the Serpentine Gallery. The sixty-eight-minute film is, in many ways, typical of Mekas' work in that he uses fragments and impressionistic filmed footage to elegiacally suggest the history of the man spanning several decades through the first person diary or journal style, that is often associated with his work. It is possible to consider that Mekas' images of external reality are used in constant observation of an 
interior life. This film bears testament and witness to his life and his intertwined relationship to the recording and editing of his films. Repeatedly in the film we see Mekas working at the editing suite and we are constantly reminded of the constructed nature of his films through this reflexivity. These are films that have an intimate and handmade quality. The film draws on edited out footage that he has kept for nearly seventy years as he moves from recording first with a Super 8 then $16 \mathrm{~mm}$, then video cameras and then small digital cameras. Renov notes the notion of return is central to Mekas' filmic work: 'But the return is always itself a reworking, a movement of recuperation and renewal, in this case to a documentary poetics from which Mekas never entirely retreated' $(2004,75)$.

\section{Figure. 1: Still images from Outtakes of a Life of a Happy Man}

Mekas' film clearly provides an opportunity to investigate the relationship between compilation film and après coup. His film is comprised of material that was initially considered to be of no significant value and left out of the final cut in the making of his earlier films. The Oxford English Dictionary defines 'outtakes' as 'a short part of a film or television programme or music recording that was removed and not included, usually because it contains mistakes'. His material for Outtakes of a Life of a Happy Man is compiled from the outtakes of his vast archive of filmmaking. It is those filmic moments which have fallen to the 'cutting room floor', that initially seemed to be without signification. At ninety years old when he made the film, these seeming throwaway segments become filled with the most moving and tender signification, as if they hold the happiness of both external and internal representation of his object relations across time. 
In an interview as part of the screening of Outtakes of a Life of a Happy Man at the Viennese Film Festival in 2013, Mekas describes his process of making the film:

In my editing room there is a shelf with many cans of film going back as far as 1950 . There are all materials that relate to my finished films, from 1950 till now, but they somehow could not find a place in them. They are, in filmmaking language, outtakes. And they are all slowly fading. Some are already faded. On the occasion of my Serpentine show, I decided that the time had come to finally collect all this footage in my final film - as film. ${ }^{6}$

It is the outtakes that become resignified après coup as being of importance for what he appears to have thought would be his final film. It can be considered that it is the reverberation between the 'now' point of time in the making of the film with the 'then' held in the outtake, which is resignified. Similarly, within psychoanalysis, it is the 'outtakes' of material from the session — the seemingly insignificant material — that acquire resignification in the dream, après coup (Virtue, 2013), and may take on new meaning retroactively in the following analytic session. A useful example of this can be seen in relation to screen memories that may become evident within a session. Screen memories refer to the production and layering of a memory to obfuscate a traumatic earlier experience. This lends itself to understanding the potential significance behind images seen on the filmic screen. ${ }^{7}$

It is possible to speculate that a similar process of resignification occurs for Mekas when he describes editing these films at night, alone in his dream-space. In the film, Mekas looks back at his life and the images and events, which brought him joy and enabled him to be a happy man. Yet, the film simultaneously points to the passage

\footnotetext{
${ }^{6}$ The full interview can be found on the Vienna Film Festival's website:

http://www.viennale.at/en/films/outtakes-life-happy-man

${ }^{7}$ See Freud's Screen Memories (1899) for a detailed exploration of this phenomenon
} 
of time, and the sense of loss and longing poignantly sits alongside the happiness. It is the most human and melancholic of films as it poetically points to both presence and absence, the present moment and as well as the past contained in memory — although he refutes the notion of the past and memory.

\section{Time, timelessness and memory}

In Mekas' work, it is possible to consider that time and memory are paradoxical in that both are evident, yet simultaneously denied. As such, there is a tension between memory and the present moment. Mekas contests that his film is about memory. However, the images, being associated with past relationships, places and events are clearly redolent with memory. The images seem poised between the past and the present through the way they are associatively edited, and through the way in which the experience is conveyed. Sitney has noted that for Mekas' 'the pixilated imagery, blazing by in fast motion, provides the central and most often repeated metaphor for the temporality of the present moment' $(2002,341)$. Although the film has been compiled from the archive, as after images, après coup, they are also of the present moment. In relation to this, Evans says: 'I would argue that the primary timeframe we experience within this film, despite by definition, a store of memory being open to us, is the presentness of Mekas' own encounter with the experience he conveys to us' (2013). The dream-like images and reveries in the film seem very alive in the present moment and it is this simultaneity of time that can be considered to come close to the timelessness of the unconscious identified by Freud (1895), where memory is laid down not once but in a multiplicity of incidences. This further connects to what Sitney has observed about the scrambled and multiplicities of time in Mekas' films. Sitney writes that Mekas' films have a 'fragmented expression' that correspond more to a diary where the 'entry dates 
have been lost and the pages scrambled' $(2002,339)$.

Mekas' work exemplifies après coup through the double temporal structure of his films. Further, Mekas' film engenders the notion of inscription, trace, absence, memory and time that enable further links to be made between compilation film and psychoanalysis. Rob Weiss, in a paper delivered at a conference on trauma eloquently writes about the relationship between absence, representation and time, which seems apt for Mekas' film too. Weiss writes:

\footnotetext{
How is trauma represented? I've suggested that trauma is represented in a relation to absence; trauma is represented in traces, trauma has specific relation to temporality and deferral, to exteriority and interiority. And that these relations and representations can be thought about in terms of the index, and its particular concerns with deferral, absence and inscription. $(2013,3)$
}

It is this preoccupation with trace, temporality and deferral that further links compilation film with psychoanalysis. Mekas' film provides an opportunity to explore après coup as an over-arching notion that may inform psychoanalytic representations of interiority in documentary film.

\section{Visual après coup}

Mekas' work opens up the possibility to explore the archive through the interconnection of the images that may then be placed in dialectical relationship to each other. This begins to create a space for the development of a visual après coup in which a new meaning may emerge through the visual reverberation between images across time. One example of this can further be seen in the work of a contemporary of Mekas, namely Harun Farocki, who along with Wolfgang Ernst advocated for a visual archive that could be arranged by 'visual concepts rather than by texts and keywords associated with the image' $(2004,261)$. Such an archive, they argue would be 'facilitated by parameters 
that can be set in contemporary data-based film archives using time code, enabling searches for shots reoccurring across an exhaustive range of disparate film productions' (Farocki and Ernst 2004, 261). An example of the use of visual concepts placed in dialectical relationship to each other can be seen in Farocki's compilation film Workers Leaving the Factory (1995), based on the Lumière brothers' historic, 45-second sequence, which bears the same name. Farocki draws on an extensive visual archive gathered from the history of film, across a multitude of geographic locations and periods, of workers leaving the factory. He intersperses these older scenes with the earlier, original footage of the Lumière brothers' workers leaving the factory. In doing so, the earlier sequence is 'read' in light of what comes after, so that the original sequence is seen as part of a critique of cinema, mechanisation and its relationship to labour (Farocki and Ernst, 2004, 237). Similarly, Mekas's archival interest in the poetics of time and memory led him to traverse his own seventy years of archive footage with the objective of paying homage to the absent edifices, which were dramatically eroded from the New York skyline.

\section{Reflection and conclusion}

Frosh points out that the notion of nachträglichkeit is linked to two conceptualisations of temporality, explored earlier in this paper. The first follows a linear causational model: what happened in the past informs how the present is understood. Implicit in this is that this early experience will have a later detrimental impact. However, the second meaning is associated with a non-linear, more circular temporality, which is considered to be specifically psychoanalytic. Here is a return to Perelberg's conceptualisation of time that includes development, regression, fixation, repetition compulsion, the return of the repressed, the timelessness of the unconscious and après coup $(2008,32)$, all falling within the master concept of après coup. This conceptualisation provides a 
uniquely psychoanalytic framework for the analysis of the construction of subjectivity in documentary film. It is this visual après coup and the figuration of this temporalised gaze in documentary film which is the central contribution of this paper.

It is also useful then to evaluate the knowledge of interiority that the notion of après coup may produce in compilation film. Frosh has noted that psychoanalytic sensemaking, by its very nature, 'is therefore carried out from the standpoint of something that has already happened and can be moulded into shape in the light of where one now finds oneself' $(2010,24)$. As mentioned above, this suggests that the archive, through the compilation film, may remain perpetually open to new meaning being conferred on it. This links the compilation film to a psychical scenography whose meaning may change from the position of a future vantage point.

The use of après coup, as Frosh notes, disrupts any stable and permanent reading of events. Rather, it opens up the archive to the unpredictability of the unconscious. This enables a more playful and fluid relationship to develop between footage and meaning in compilation film. However, this comes at a price as its truth claims are always relative and its stance ambiguous.

To conclude, this paper has been concerned with how compilation film may give form, through analogous relationship, to the representations of experience in the mind. Using the notion of après coup, or afterwardsness, it argues that signification is produced retroactively, that is, it is formed through the dialectical reverberation of experiences across different temporalities. Through the editing of archival footage into a new a timeline, compilation film may begin to reflect and evoke the temporality more associated with the unconscious. It may repurpose footage to visually suggest the timelessness of the unconscious and après coup. While the self-referential nature of compilation film makes its construction explicit, it should be noted that due to 
documentary film's two-fold process of filming and editing, there is always a process of après coup, a resignification afterwards, even when the text itself suggests a continuity of time and place.

\section{References}

Barthes, R. 1980. Camera Lucida. Trans. by R. Howard. New York: Hill and Wang.

Baudry, J.L. \& Williams, A. 1974. Ideological Effects of the Basic Cinematographic Apparatus in Film Quarterly, 28, pp.39-47.

Benjamin, W., \& Tiedemann, R. 1999. The Arcades Project. Cambridge, Mass: Harvard University Press.

Birksted-Breen, D. 2003. Time and the après-coup. The International Journal of Psychoanalysis, 84(6), 1501-1515. doi:10.1516/1DM9-6X63-248B-U5F6

Chanan, M. 2007. The Politics of Documentary. London: British Film Institute.

Cournut, J. 1999. The Meaning of Deferred Action. In Journal of the American Psychoanalytic Association, Volume: 47 issue: 1, page(s): 213-225.: February 1, 1999.

Cowie, E. 1999. The Spectacle of Actuality in J. M. Gaines \& M. Renov (eds.)

Collecting Visible Evidence. Minneapolis: University of Minnesota Press, pp. 19-45.

Cowie, E. 2011. Recording Reality, Desiring the Real. London \& Minneapolis:

University of Minnesota Press.

Derrida, J. 1996. Archive fever: A Freudian Impression. Chicago: University of Chicago Press.

Doane, M. A. 2002. The Emergence of Cinematic Time: Modernity, Contingency, the Archive. Cambridge, Mass.: Harvard University Press

Evans, G. 2013. Response to Jonas Mekas Outtakes of a Life of a Happy Man (2012), Paper presented at the Psychoanalysis and Documentary Film Conference, University College London, London, $4^{\text {th }}$ May 2013.

Farocki, H. and Ernest, W. (2004). Towards and Archive for Visual Concepts. In: Elsaesser, T. (ed.). Harun Farocki Working on the Sightlines. Amsterdam: Amsterdam University Press, pp. 261-286.

Fletcher, J. 2013. Freud and the Scene of Trauma. Oxford: Oxford University Press.

Fonagy, P., \& Target, M. 2003. Psychoanalytic Theories: Perspectives from Developmental Psychopathology. London: Whurr publishers. 
Freud, S. 1895. Project for a scientific psychology. In J. Strachey (ed.), The Standard Edition of the Complete Works of Sigmund Freud Vol. I. London: Hogarth.

Freud, S. (1899). Screen memories. In J. Strachey (ed.), The Standard Edition of the Complete Works of Sigmund Freud, Vol. 3, 301-322. London: Hogarth.

Freud, S. (1918). From the history of an infantile neurosis. In J. Strachey (ed.), The Standard Edition of the Complete Works of Sigmund Freud, Vol. 17, 3-123. London: Hogarth.

Freud, S. (1925). A Note upon the 'Mystic Writing-Pad'. In J. Strachey (ed.), The Standard Edition of the Complete Works of Sigmund Freud, Vol. 19, 227-232. London: Hogarth.

Freud, S. 1930. Civilization and its Discontents. In J. Strachey (ed.), The Standard Edition of the Complete Works of Sigmund Freud, Vol. 21, 59-145. London: Hogarth.

Frosh, S. 2010. Psychoanalysis Outside the Clinic. New York: Palgrave Macmillan.

Hall, S. 1997. The Work of Representation. In: S, Hall, (ed.), Representation: Cultural Representations and Signifying Practices, London: Sage, pp. 13-74

Laplanche, J. 1999. Essays on Otherness. London: Routledge.

Laplanche, J., \& Pontalis, J,-B. 1973. The Language Of Psychoanalysis. London: The Hogarth Press Ltd. Reprinted Karnac (1988).

Laplanche, J., \& Pontalis, J. B. 1985. Fantasme originaire. Fantasmes des origines, Origines du fantasme, Paris, Hachette.

Lebeau, V. (2001) Psychoanalysis and Cinema: the Play of Shadows. London \& New York: Wallflower Press \& Columbia University Press.

Leyda, J. 1964. Films Beget Films. Hill and Wang.

Lippit, A. M. (1999). Phenomenologies of the Surface: Radiation-body-image. In Gaines, J. \& Renov, M. (eds.) Collecting Visible Evidence (pp.65-83). Minneapolis: University of Minnesota Press.

MacCabe, C. 1985. Theoretical Essays: Film. Linguistics, Literature. Manchester: Manchester University Press.

MacDougall, D. 1998. Transcultural Cinema. Princeton, N.J.: Princeton University Press.

Masson, J. M. (1984). Freud: The assault on truth: Freud's suppression of the seduction theory. London: Faber \& Faber.

Metz, C. 1988 (1982) Psychoanalysis and Cinema: The Imaginary Signifier. Trans. by C. Britton, A. Williams, B. Brewester \& A. Guzzetti. London: Macmillan. 
Mulvey, L. 1975. Visual pleasure and narrative cinema. Screen, 16(3), 4-5. doi:10.1093/screen/16.3.4

Mulvey, L. 2007. Compilation Film as 'Deferred Action': Vincent Monnikendam's Mother Dao, the Turtle-like. In: Sabbadini, A. (ed.) Projected Shadows. Psychoanalytic Reflections on the Representation of Loss in European Cinema. London: Routledge, pp. 109-131.

Nichols, B. 1991. Representing Reality: Issues and Concepts in Documentary. Bloomington: Indiana University Press.

Nichols, B. 1993. “Getting to Know You...”. Knowledge, Power, and the Body in M. Renov Theorizing Documentary. Minneapolis: The University of Minnesota Press, pp.174-191.

Perelberg, R. J. 2008. Time, Space and Phantasy. London: Routledge.

Piotrowska, A. 2013. Psychoanalysis and Ethics in Documentary Film. London: Routledge.

Piotrowska, A. 2014. Nachträglichkeit and après coup in documentary film. In: Piotrowska, A. (ed.), Embodied Encounters: New approaches to Psychoanalysis and Cinema. London: Routledge, pp. 22-35.

Renov, M. 1993. Theorizing Documentary. Minneapolis: The University of Minnesota Press.

Renov, M. 2004. The Subject of Documentary. Minneapolis: The University of Minnesota Press.

Renov, M. 2004. Lost, Lost, Lost: Mekas as Essayist. In: The Subject of Documentary. Minneapolis: The University of Minnesota Press, pp. 69-92.

Renov, M. 2014. Documentary and Psychoanalysis: putting the love back in epistephilia. In: Piotrowska, A. (ed.), Embodied Encounters: New approaches to Psychoanalysis and Cinema. London: Routledge, pp. 147-156.

Rushton, R. 2004. The psychoanalytic structure of trauma: Spellbound. Journal for Cultural Research 8.3 (2004): 371-384.

Sitney, P. A. 2002. Visionary Film: The American Avant-Garde, 1943-2000. Oxford: Oxford University Press.

Spence, D. P. 1982. Narrative Truth and Historical Truth: Meaning and interpretation in psychoanalysis. New York; London: Norton.

Sutton, P. 2004. Afterwardsness in film. Journal for Cultural Research 8.3 (2004): 385405.

Sjöberg, P. 2001. The World in Pieces - A Study on Compilation Film. Stockholm: Aura forlag. 
Sodre, I. 1999. Insight and Deferred Action. In Journal of the American Psychoanalytic Association, Volume: 47 issue: 1, page(s): 213-225.: February 1, 1999.

Smaill, B. 2010. The Documentary: Politics, Emotion, Culture. New York: Palgrave Macmillan.

Virtue, M. 2013. "Après Coup", Paper presented at the Psychoanalysis and Documentary Film Conference, University College London, London, $4^{\text {th }}$ May 2013.

Walker, J. (2005). Trauma Cinema: Documenting Incest and the Holocaust. Berkeley, London: University of California Press.

Wees, W. C. 1993. Recycled Images: The Art and Politics of Found Footage Films. New York City: Anthology Film Archives.

Weiss, R. 2013. Between Experience and Representation: Towards a Semiotics of Trauma, The Site for Contemporary Psychoanalysis, Number 9, Winter 2013.[Online]. Available at: http://www.the-site.org.uk/sitegeist/issue-9/between-experience-andrepresentation-towards-a-semiotics-of-trauma/ [Accessed 19 June 2017].

\section{Filmography}

Farocki, H. 1995. Workers Leaving the Factory.

Mekas, J. 2010. Outtakes of a Life of a Happy Man. Anthology Film Archive. 
Figure 1: Stills from Outtakes of a Life of a Happy Man (2012)
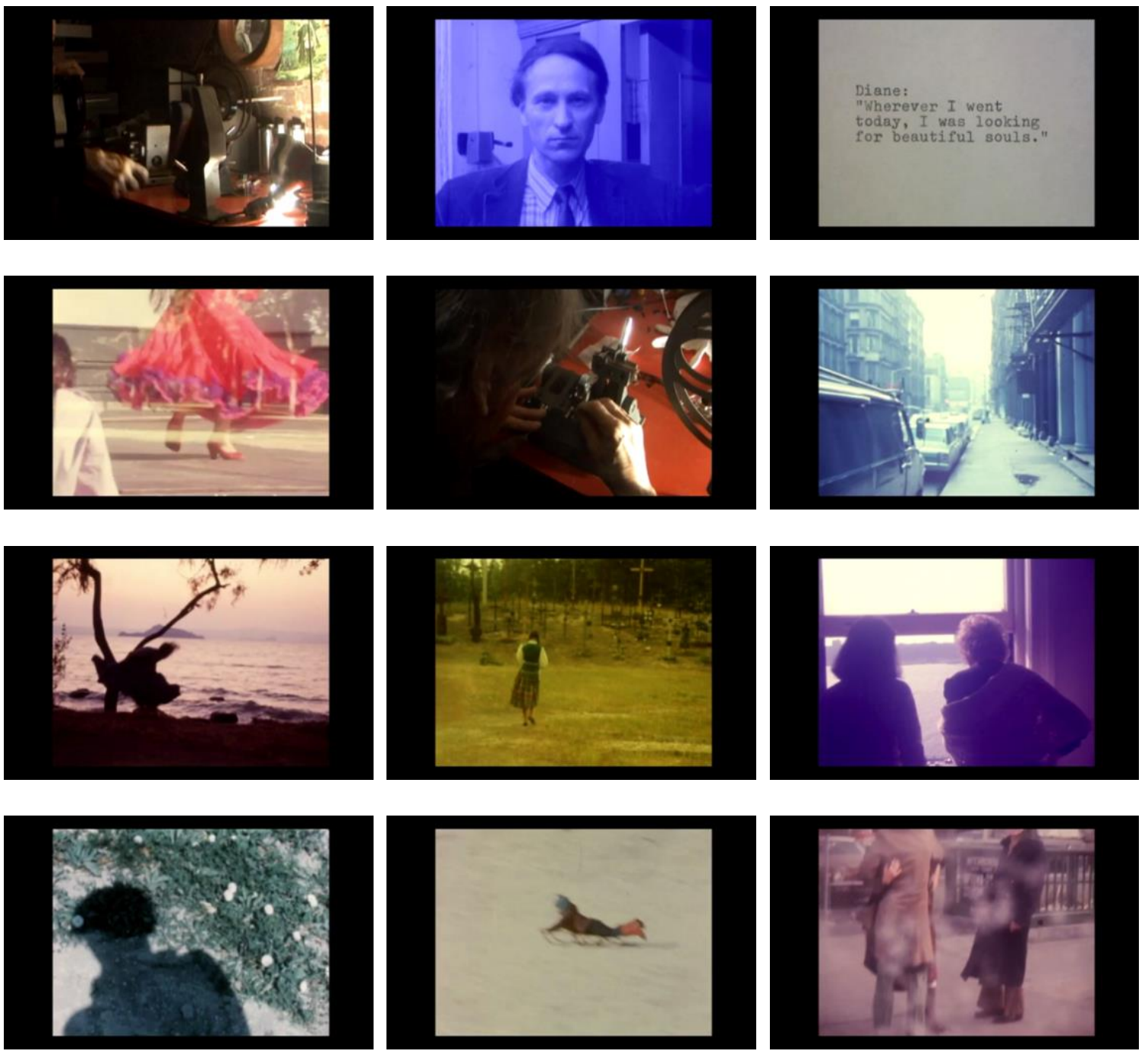

Figure 1. Stills from Outtakes of a Life of a Happy Man (2012). Copyright consent still to be received. 